AWEJ for translation \& Literary Studies volume, 1 Number1. February 2017 http://dx.doi.org/10.24093/awejtls/vol1no1.2

\title{
Intellectuals, Politicians, and the Public in Chinua Achebe's A Man of the People: A Postcolonial Critique
}

\author{
Shadi Saleh Ahmad Neimneh \\ English Department \\ Hashemite University, Zarqa, Jordan \\ Amneh Khaleel Hussein Abussamen \\ Zarqa, Jordan
}

\begin{abstract}
This paper sheds light on the possible hope for the Nigerian situation in Chinua Achebe's A Man of the People (1966), away from bankrupt intellectuals, corrupt politicians, and an ignorant public. This novel portrays two schools of ineffectual native educators who seem to be antagonists: the traditional old school and the new modern intellectuals. Postcolonial/race theories of Fanon, Appiah, Du Bois, and Woodson as well as Gramsci's notion of the "organic intellectual" are employed to get a clearer image of the role of intellectuals and politicians in shaping the future of a country in the post-independence era. The article concludes that intellectuals with European education may contribute to the corruption of their country due to reasons like divided loyalties, miseducation, and lack of communication with the public. Additionally, Achebe is critical of the current politicians and the excluded public. So, our analysis employs Woodson's concept of "the miseducation of the Negro" because such "miseducation" produces incompetent politicians like Chief Nanga, weak intellectuals like Odili Samalu, and ignorant people like the public in the novel. Real hope against governmental corruption in Achebe's satirical novel can be found in integrating the class of intellectual/political leaders and the public and in a different kind of indoctrination, neither colonial nor neo-colonial. The truly educated class and the "organic intellectuals" produced from the public are key solutions for a better "Nigeria." Hence, this article highlights the role of politicized education in post-independence nation building and tackles the mishaps of nascent nationalism.
\end{abstract}

Keywords: Chinua Achebe, Intellectuals, Politics, Postcolonialism, the Public

Cite as: Neimneh, S.A. \& Abussamen, A. H. (2017). Intellectuals, Politicians, and the Public in Chinua Achebe's A Man of the People: A Postcolonial Critique. Arab World English Journal for Translation \& Literary Studies, 1(1). DOI:http://dx.doi.org/10.24093/awejtls/vol1no1.2 